\title{
Discours touchant. La méthode de la certitude et l'art d'inventer
}

Pour finir les disputes et pour faire en peu de temps des grands progrès

Wilhelm Leibniz

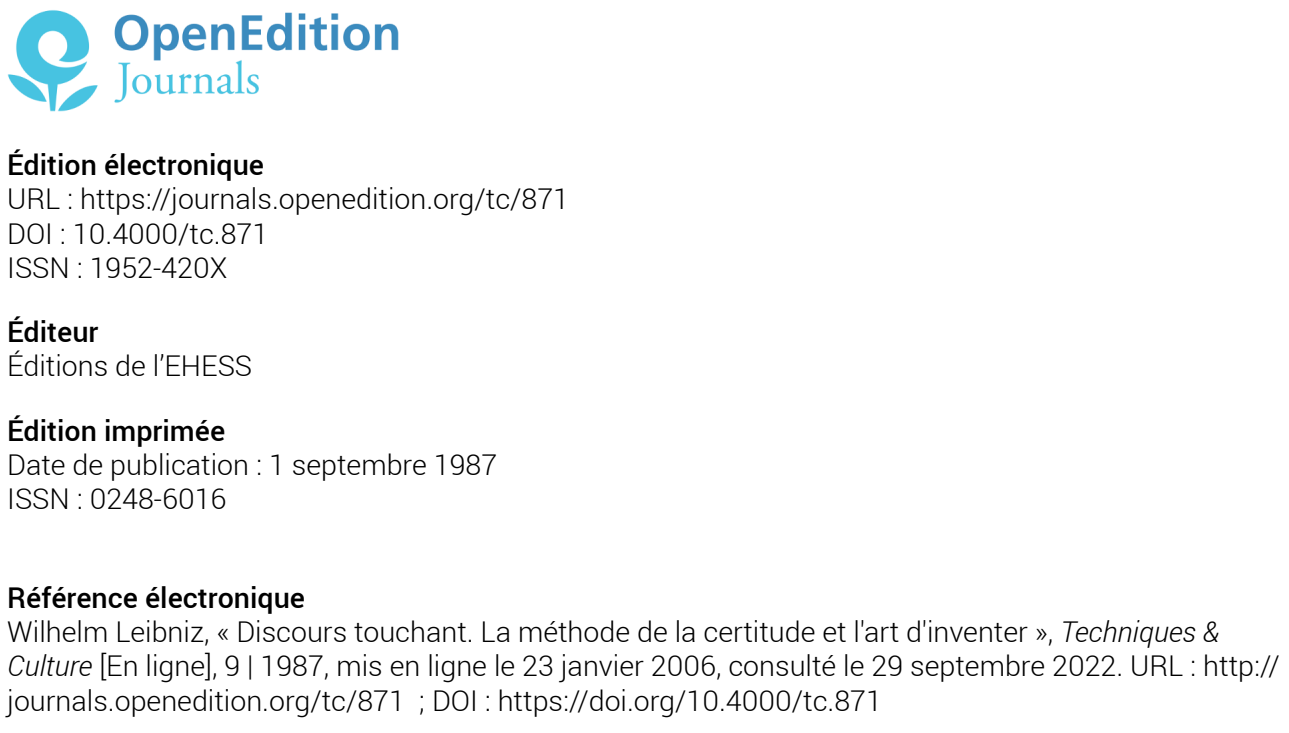

Ce document a été généré automatiquement le 29 septembre 2022.

Tous droits réservés 


\section{Discours touchant. La méthode de la certitude et l'art d'inventer}

Pour finir les disputes et pour faire en peu de temps des grands progrès

Wilhelm Leibniz 